\title{
STUDI ALQURAN DAN INTEGRASI KEILMUAN: STUDI KASUS UIN SUNAN GUNUNG DJATI BANDUNG
}

\author{
Syahrullah Iskandar \\ Dosen Fakultas Ushuluddin UIN Sunan Gunung Djati Bandung \\ Jl. A.H. Nasution 105 Cibiru, Bandung 40614, Indonesia. \\ E-mail: syahrullah_iskandar@yahoo.com
}

\begin{abstract}
Quranic studies constitute a basis for developing Islamic studies. Quranic studies support the concept of integration of knowledge by accommodating the scientific findings into the revealed Qur'anic dimension. This article investigates the role of Qur'anic studies in the process of knowledge integration and its application at Ushuluddin Faculty, State Islamic University, Bandung. This article shows that in term of curricula and methods of learning, Ushuluddin Faculty provides accommodative response to the knowledge integration model. Some notes to be considered, however, is to include dynamic and progressive method of understanding the Qur'an in relation to current situation in reality. Thus, an approach 'from reality to the text' in studying the Qur'an is required to accommodate the concept of knowledge integration.
\end{abstract}

Keywords:

Qur'anic studies; knowledge integration; reality; text

\begin{abstract}
Abstrak
Studi Alquran merupakan pijakan dasar dari pengembangan studi keislaman. Studi Alquran dapat mendukung upaya integrasi keilmuan dengan cara akomodasi penemuan ilmiah yang sistematis dengan tetap mengacu pada basis kewahyuan Alquran. Tulisan ini memaparkan tentang studi Alquran dan integrasi keilmuan yang diterapkan pada Fakultas Ushuluddin Univessitas Islam Negeri Sunan Gunung Djati Bandung. Tulisan ini menyimpulkan bahwa Fakultas Ushuluddin pada tataran kurikulum dan sistem pembelajaran sudah menunjukkan upaya akomodatif terhadap integrasi keilmuan tersebut. Beberapa hal yang perlu mendapatkan perhatian adalah membuka peluang bagi metodologi yang lebih terbuka dengan memperhatikan perkembangan zaman untuk memicu penelitian yang berbasis realitas. Dengan demikian, pendekatan dari realitas ke teks dalam studi Alquran menjadi sebuah keniscayaan dalam upaya integrasi keilmuan.
\end{abstract}

Kata Kunci:

Studi Alquran; integrasi keilmuan; realitas; teks

DOI: http://dx.doi.org/10.15575/jw.v39i1.580

Received: November 2015 ; Accepted: December 2015 ; Published: February 2016

\section{A. PENDAHULUAN}

Islam sebagai objek studi merupakan topik yang atraktif diperbincangkan di kalangan ilmuwan. Gejala pada agama yang dapat dijadikan objek studi semisal scripture, penganut dan/atau pemuka agama, ritus, lembaga, atau ibadat-ibadat, alat-alat seperti masjid, dan organisasi keagamaan ${ }^{1}$ adalah 'lahan empuk' yang selalu 'seksi' untuk diselami secara ilmiah. Bahkan, pengembangan keilmuan Islam dapat diulas dalam

${ }^{1}$ Atho Mudzhar, Pendekatan Studi Islam dalam Teori dan Praktik (Yogyakarta: Pustaka Pelajar, 2004), cet. V, 13-14. varian perspektif untuk menghasilkan ilmu yang aktual. Ciri pembeda dari kajian keislaman ini adalah pada rambu dogmatiknya, khususnya pada dimensi sakralitas yang integratif oleh Islam itu sendiri. Dengan tetap memerhatikan dimensi sakralitasnya, studi Islam menjadi tantangan tersendiri bagi seorang akademisi untuk memosisikan sebuah paradigma dan kerangka teoretis, serta menjalani metodologi yang tepat dalam menggali hakikat Islam sebagai objek studi. Oleh karena itu, topik integrasi keilmuan menemukan momentum performatifnya untuk diurai, terutama dalam kaitannya dengan studi Alquran, khususnya di lingkungan Fakultas 
Ushuluddin Universitas Islam Negeri Sunan Gunung Djati (UIN SGD), Bandung.

Studi Alquran merupakan mata kuliah pokok di perguruan tinggi Islam di semua fakultas dan jurusan. Untuk lingkup Fakultas Ushuluddin, studi Alquran tersaji dalam varian mata kuliah seperti Ulumul Qur'an dan Tafsir. Kesemua mata kuliah tersebut tersaji di semua jurusan di lingkungan Fakultas Ushuluddin. Penyajian mata kuliah ini terbilang penting mengingat objek pembahasannya adalah Alquran yang merupakan dasar dan pokok studi keislaman. Konsekuensi dari pengkajian terhadap Alquran telah melahirkan varian disiplin keilmuan yang mengalami perkembangan sesuai konteks spasial-temporal. Salah satu aspek interaktif dari pengkajian studi Alquran adalah ketika mengaitkannya dengan pengembangan konsep integrasi keilmuan.

\section{B. HASIL DAN PEMBAHASAN \\ 1. Konsep Integrasi Keilmuan}

Secara leksikal, term 'integrasi' berasal dari kata Inggris integration dari kata kerja integrate yang berarti menggabungkan, menyatupadukan, mempersatukan, atau mengintegrasikan. Makna leksikal dari kata integrasi ini dapat diartikan sebagai penggabungan atau penyatuan beberapa hal menjadi satu kesatuan yang solid dan utuh dan tidak dapat dipisah-pisahkan. Secara konsep keilmuan, tidak ada pemisahan antara satu disiplin keilmuan dengan disiplin keilmuan lainnya. Semuanya berjalan menurut konteksnya dan saling melengkapi satu sama lain dan memberi manfaat dalam kehidupan manusia.

Jika ditinjau historisitasnya, konsep integrasi keilmuan bukanlah barang baru, karena telah didiskusikan oleh ulama-ulama klasik Islam. Sebagai contoh, al-Syafi'i dalam karya monumentalnya al-Umm, mendasari uraian master piece-nya itu dengan memosisikan Alquran dan Hadis sebagai sumber utama keilmuan. Kedua pedoman tersebut menetapkan prinsip dasar dan petunjuk bagi manusia untuk meraih kebahagiaan hidup di dunia dan akhirat. Senada dengannya, ulama klasik Islam lainnya memadukan tiga aspek dalam upaya integrasi keilmuan: spiritual, intelektual, dan moral. Keterkaitan ketiga aspek tersebut disejajarkan dengan eratnya kepaduan antara akidah, syariah, dan akhlak. Dalam format serupa, al-Ghazali mendeskripsikan kepaduan tiga aspek, yaitu qalb (hati), 'aql (intelektualitas), dan nafs (nafsu). Dan, tidak kalah menariknya adalah ketika Ibn Khaldun menjelaskan bahwa keilmuan manusia merupakan fenomena alami manusia yang bersumber dari dua rujukan utama, yaitu wahyu (revelation) dan alam (the universe). ${ }^{2}$ Ulasan ini menjadi dalil tak terbantahkan bahwa perbincangan tentang integrasi keilmuan juga telah lebih dulu hadir sebelum diwacanakan beberapa dasawarsa terakhir. Bahkan, wacana integrasi ilmu oleh ulama klasik sudah memperbincangkan tentang kelanjutan dari konsep itu, yang dapat disebut 'melampaui konteks zamannya'.

Istilah yang sering dipadankan dengannya "integrasi keilmuan" adalah "islamisasi pengetahuan" (islamization of knowledge) yang meniscayakan dua prinsip utama. Pertama, Sumber utama dari semua ilmu dan pengetahuan adalah Alquran dan Hadis; Kedua, Metode yang ditempuh untuk memperoleh ilmu dan pengetahuan haruslah islami. Untuk mewujudkan upaya tersebut, dibutuhkan pemenuhan 4 (empat) kriteria, yaitu alam, hukum alam, pengajaran yang islami (prinsip dan arahan), dan nilai Islam (moral dan estetika). ${ }^{3}$ Oleh Kuntowijoyo, pokok dari konsep integrasi adalah penyatuan (bukan sekadar penggabungan) antara wahyu Tuhan dan temuan pikiran manusia. ${ }^{4}$ Menurutnya, konsep integrasi adalah memberi proporsi yang layak bagi Tuhan dan manusia dalam keilmuan. Dengan begitu, integrasi keilmuan bukanlah 'sekularisme', bukan juga 'asketisisme'. Ia diharapkan dapat menyelesaikan konflik antara sekularisme ekstrem dan

${ }^{2}$ W. Mohd Azam. Mohd Amin, "A Preliminary Analysis of The Classical Views of The Concept of Integration of Knowledge," Revelation and Sciences 04, no. 02 (2014): 14.

${ }^{3}$ Fouzia Ferdous dan Muhammad Athar Uddin, "Toward Islamization of Science and Technology," IIUC Studies Vol. 9, no. 9 (2011): 236.

${ }^{4}$ Kuntowijoyo, Islam sebagai Ilmu (Yogyakarta: Tiara Wacana, 2006), 55. 
agama-agama radikal dalam banyak sektor. Senada dengan itu, Imam Suprayogo juga mendefinisikan integrasi keilmuan sebagai pemosisian Alquran dan Hadis sebagai grand theory bagi pengetahuan. 5 Dengan begitu, argumentasi naqli tersebut dapat terpadukan dengan temuan ilmu.

Lahirnya konsep integrasi dilatari oleh dikotomi antara ilmu-ilmu agama dan ilmuilmu umum. Keduanya terpisahkan dan seolah berjalan pada wilayahnya masing-masing. Ia juga dipicu oleh separasi antara sistem pendidikan Islam dan sistem pendidikan modern yang berdampak laten bagi umat Islam. Asumsi yang berkembang adalah "ilmu tidak peduli dengan agama, begitupun (sebaliknya) agama abai terhadap ilmu”. Hal ini juga berimplikasi pada berkembangnya slogan "ilmu untuk ilmu", yang acapkali menapikan nilai etika dalam implementasinya. Ilmu dan agama seolah dua entitas yang berlainan dan terpisah satu sama lain, mempunyai wilayah masing-masing, baik objek formal-material keilmuan, metode penelitian, kriteria kebenaran, peran yang dimainkan oleh ilmuwan, bahkan ke tingkat institusi penyelenggaranya. ${ }^{6}$

Beberapa model integrasi keilmuan yang telah ada dapat menjadi inspirasi dan pijakan untuk memperkaya upaya integrasi keilmuan. Beberapa model tersebut yaitu: a) IFIAS (International Federation of Institutes of Advance Study), yaitu tidak ada pemisahan antara sarana dan tujuan sains, karena keduanya harus tunduk pada landasan etika dan nilai keimanan. Dengan kata lain, upaya intelektualitas harus tunduk pada batasan etika dan nilai Islam; b) ASASI (Akademi Sains Islam Malaysia), yaitu pelibatan nilai-nilai dan ajaran Islam dalam kegiatan penelitian ilmiah. Model ini dikembangkan sejak tahun 1977 di Malaysia; c) Islamic Worldview, yaitu menempatkan pandangan dunia Islam sebagai

${ }^{5}$ Imam Suprayogo, "Membangun Integrasi Ilmu dan Agama: Pengalaman UIN Malang," in Integrasi Ilmu dan Agama: Interpretasi dan Aksi, ed. Zainal Abidin Bagir (Bandung: Mizan, 2005), 49-50.

${ }^{6}$ Amin Abdullah, Islamic Studies di Perguruan Tinggi: Pendekatan Integratif-Interkonektif (Yogyakarta: Pustaka Pelajar, 2012), 92. dasar bagi epistemologi keilmuan Islam secara menyeluruh dan integral. Model ini dikembangkan oleh Alparslan Acikgene; d) Struktur Pengetahuan Islam, yaitu bahwa secara sistematik, pengetahuan telah diorganisasikan dan dibagi ke dalam sejumlah disiplin akademik. Model ini sebagai bagian dari upaya mengembangkan hubungan yang komprehensif antara ilmu dan agama. Model ini digagas oleh Osman Bakar; e) Bucaillisme, yaitu mencari kesesuaian penemuan ilmiah dengan ayat Alquran. Model ini dikembangkan oleh Maurice Bucaille, ahli Medis Perancis; f) Berbasis Filsafat Klasik, yaitu berusaha memasukkan tauhid dalam skema teorinya. Allah SWT diposisikannya sebagai kebenaran yang hakiki, sedangkan alam hanya merupakan wilayah kebenaran terbawah. Model ini digagas oleh Seyyed Hossein Nasr; g) Berbasis Tasawuf, yaitu memosisikan deislamisasi sebagai westernisasi. Model ini diinisiasi oleh Syed Muhammad Naquib alAttas; h) Berbasis Fikih, yaitu menjadikan Alquran dan Hadis sebagai puncak kebenaran. Model ini dikembangkan oleh Ismail Raji' alFaruqi dengan tidak menggunakan warisan sains Islam; i) Kelompok Ijmali, yaitu menggunakan kriterium ' $a d l$ dan menjalankan konsep integrasinya. Model ini juga tidak menjadikan warisan sains Islam klasik sebagai rujukan. Model ini dipelopori oleh Ziauddin Zardar; j) Kelompok Aligargh, yaitu bahwa sainsi Islam berkembang dalam suasana 'ilm dan tashkir untuk menghasilkan ilmu dan etika. Model ini digagas oleh Zaki Kirmani di India. ${ }^{7}$

Dari semua model yang dipaparkan, terlihat bahwa ilmu sekuler (manusia) berada di bawah sumber ilmu yang hakiki, yaitu Tuhan. Dengan begitu, Alquran (dan Hadis) menjadi sumber dan rujukan utama. Standarisasi etika menjadi 'komoditas' utama yang harus disertakan dalam upaya integrasi keilmuan. Tinjauan berbeda diuraikan oleh Kuntowijoyo dengan mengenalkan model lain yang lebih

\footnotetext{
${ }^{7}$ Nur Jamal, "Model-Model Integrasi Keilmuan (Format Ideal Perguruan Tinggi Agama Islam)," Islamedia: Jurnal Kajian Keislaman Vol. 1, no. 1 (2011): 197.
} 
"mengapresiasi" ilmu sekuler. Menurutnya, ilmu-ilmu sekuler merupakan produk bersama umat manusia, sedangkan ilmu integralistik (nantinya) adalah produk bersama seluruh manusia beriman. Ia menegaskan bahwa kita semua sekarang ini adalah produk, partisipan, dan konsumen ilmu-ilmu sekuler, sehingga tidak boleh dipandang rendah. Apresiasi terhadap ilmu sekuler dapat dilakukan dengan mengkritisi dan meneruskan perjalanannya. Sumber pengetahuan itu ada dua, yaitu yang berasal dari Tuhan (revealed knowledge) dan yang berasal dari manusia (secular), yang keduanya diistilahkannya dengan teoantroposentrisme. Diakuinya bahwa ilmu-ilmu sekuler saat ini sedang terjangkiti krisis (tidak dapat memecahkan banyak persoalan), mandek (tertutup untuk alternatif-alternatif), dan mengandung bias-bias seperti filosofis, peradaban, keagamaan, ekonomis, etnis, gender, politik, dan selainnya. ${ }^{8}$

\section{Perspektif Alquran}

Pada dasarnya, Alquran tidak mengenal prinsip dikotomi antara ilmu agama ataupun ilmu non-agama. Bahkan, Alquran sangat menganjurkan agar setiap orang memerhatikan ayat-ayat qawliyah (Alquran), di samping menggunakan akal dalam memahaminya. Dalam konteks penggunaan akal inilah, utilitas disiplin ilmu-ilmu non-agama yang berbasis pada penalaran ilmiah yang sistematis diperlukan.Kombinasi antara Alquran dan ilmu-ilmu non-agama merupakan sebuah kemestian dalam mengembangkan studi Alquran. Pasalnya, jika tidak mengakomodasi pendekatan ilmiah dalam pengkajian Alquran, maka produk pengkajiannya pun akan bersifat "melangit", alias "tidak memijakkan kakinya di bumi". Hal demikian akan berdampak pada minimnya animo pengkaji Alquran untuk menjadikan Alquran sebagai objek kajian.

Sejumlah ayat Alquran menyebutkan urgensi konteks integrasi keduanya. Konsep ulul albāb yang tersebut dalam QS. Ali 'Imran 3: 190 mensyaratkan kombinasi dua konsep sekaligus, yaitu dhikr dan fikr. Konsep dhikr

\footnotetext{
${ }^{8}$ Kuntowijoyo, Islam sebagai Ilmu, 50.
}

menandai dimensi ulūhiyah (ketuhanan), sementara konsep fikr merupakan dimensi ilmiah. Keduanya harus diintegrasikan agar melahirkan konsep keilmuan yang bernilai.

Akomodasi terhadap konteks ilmiah dalam studi Alquran sangatlah urgen. Hal demikian dapat mengungkap nilai-nilai integratif dalam ayat Alquran itu sendiri, di samping memberi 'legalitas ilahiyah' dari temuan ilmiah kekinian. Studi seperti ini terbilang menarik dan telah menarik atensi pengkaji Alquran. Tersebutlah sejumlah buku semisal Alquran dan Lautan karya Agus S. Djamil (Mizan), alTafsir al-'Ilmi karya Kementerian Agama RI, dan selainnya. Kajian-kajian mereka berupaya menawarkan penjelasan ilmiah terhadap ayatayat Alquran yang memiliki isyarat-isyarat ilmiah.

Sebagai contoh adalah QS. al-Rūm 30: 48 dan QS. al-Nūr 24: 43 yang menjelaskan tentang siklus air. Dalam kedua ayat tersebut, tidak ditemukan penjelasan rinci mengenai siklus air. Namun, kedua ayat tersebut hanya menjelaskan beberapa bagian dari proses keseluruhannya. Ayat-ayat tersebut menjelaskan tahapan-tahapan pembentukan awan yang menghasilkan hujan, sebagai salah satu bagian dari proses pembentukan siklus air. Terdapat dua fenomena dari penjelasan kedua ayat tersebut, yaitu penyebaran awan dan penyatuan awan. Kedua proses yang berlawanan inilah yang menyebabkan terbentuknya awan hujan. QS. al-Rūm 30: 48 menjelaskan tentang awan berlapis (stratus) yang hanya akan terbentuk jika angin bertiup secara bertahap dan perlahan mendorong awan ke atas. Selanjutnya, awan tersebut akan berbentuk seperti lapisan-lapisan yang melebar. ${ }^{9}$

\section{Fakultas Ushuluddin}

Fakultas Ushuluddin merupakan "mother of Islamic science" (induk ilmu keislaman) karena di dalamnya dikaji pokok-pokok ajaran Islam yang menjadi sumber pengembangan fakultas-fakultas lain di UIN SGD Bandung. Atas dasar itu, visi fakultas Ushuluddin

\footnotetext{
${ }^{9}$ Kementerian Agama RI, Penciptaan Manusia dalam Perspektif al-Qur'an dan Sains (Jakarta: Kemenag RI dan LIPI, 2012), 165.
} 
adalah: "Menjadi pusat studi dan informasi keushuluddinan yang unggul, kompetitif, dan layak bersaing". Visi tersebut dijabarkan dalam misinya yaitu "Mengembangkan pemahaman keislaman yang membumi dalam nuansa keindonesiaan dan kemodernan menuju masyarakat madani”.

Secara operasionalnya, Fakultas Ushuluddin UIN SGD Bandung hingga semester genap tahun ajaran 2014-2015 terdiri dari empat program studi, yaitu 1) Tafsir Hadis; 2) Perbandingan Agama; 3) Aqidah Filsafat; dan 4) Tasawuf Psikoterapi. Akan tetapi, sejak tahun ajaran semester ganjil 20152016, program studi tersebut mengalami pengembangan menjadi lima program studi. Program studi Tafsir Hadis yang merupakan jurusan yang paling banyak mahasiswanya dimekarkan menjadi dua program studi tersendiri, yaitu 1) Ilmu Alquran dan Tafsir dan 2) Ilmu Hadis. Adapun program studi lainnya belum mengalami pemekaran, sehingga jumlahnya sekarang sebanyak lima program studi.

Dari segi pembelajaran, metode yang diterapkan di Fakultas Ushuluddin adalah bersifat integral-terpadu dalam visi epistemologi Islam yang bercirikan: menolak dikotomi ilmu dan agama, membangun pengetahuan quranik yang holistik, tidak hanya memakai pendekatan empiris, rasionalis, atau intuitif semata, melainkan juga memadukan berbagai pendekatan secara harmonis. Di samping itu, Fakultas Ushuluddin juga mengedepankan pengembangan pemikiran yang bersifat induktif-deduktif, melalui perkuliahan yang diskursif, kritis, dan kreatif.

Mengacu ke profil Fakultas Ushuluddin, terdeskripsi dengan jelas bahwa kurikulum diarahkan untuk mencapai tiga sasaran: a) profesionalisme, yaitu pendekatan profesi keilmuan untuk kebutuhan lapangan kehidupan, terutama yang berhubungan dengan keagamaan (mental-spiritual); b) keilmuan, mengembangkan metodologi keilmuan yang menjadi bidang garapannya; dan c) keislaman, yaitu merealisasikan misi Islam dalam kehidupan. Waktu kuliah ditempuh 3,5 hingga
4 tahun, dengan Sistem Kredit Semester (SKS) yang berjumlah 144-150 SKS yang disajikan selama 7 hingga 8 semester. ${ }^{10}$

\section{Implementasi}

Upaya integrasi keilmuan adalah sebuah tugas yang harus terejawantah di UIN SGD Bandung. Sesuai visinya, "Menjadi Perguruan Tinggu Islam yang Unggul dan Kompetitif, Mampu Mengintegrasikan Ilmu Agama dan Ilmu Umum di Asia Tahun 2029."11 Dari lingkup pembelajaran di Fakultas Ushuluddin, tergambar besarnya potensi dalam implementasi integrasi keilmuan: a) ilmu dasar keislaman tersajikan dalam proses pembelajarannya; b) studi Alquran, yang tentu saja bukan sekadar bersifat verbal, melainkan disertai pemahaman yang mendalam atas isi kandungan kitab suci terakhir tersebut; c) mengintegrasikan kearifan lokal (local wisdom) sehingga mampu menjawab persoalan keseharian konteks "kedisinian"; d) mengadaptasi kemodernan sehingga dapat terus eksis dalam perkembangan dunia dan keilmuan dan menjawab persoalan dalam konteks "kekinian".

Fakultas Ushuluddin diharapkan berkontribusi dalam upaya integrasi keilmuan di lingkungan UIN SGD Bandung. Pasalnya, dalam kaitannya dengan penerapan konsep integrasi keilmuan, UIN SGD Bandung belum menemukan rumusan operasional (di tingkat pimpinan) dalam mengimplementasikan konsep integrasi keilmuan dalam kurikulum, sehingga perlu penyelarasan kurikulum. Dalam proses pembelajaran juga masih demikian, yaitu masih mengandalkan kreativitas dan inovasi individu dosen di setiap fakultas dalam menerapkan integrasi keilmuan dalam proses pembelajaran. Dengan begitu, rumusan operasional kebijakan pimpinan masih absen. Penelitian yang dilakukan Nurlena Rifai (et al.) menemukan bahwa UIN

\footnotetext{
${ }^{10}$ Data tentang Fakultas Ushuluddin sepenuhnya penulis adaptasi dari profil Fakultas Ushuluddin UIN SGD Bandung.

${ }^{11}$ Lihat header website UIN Sunan Gunung Djati Bandung, Diakses 2 November 2015, http://www.uinsgd.ac.id/
} 
Jakarta dan UIN Bandung sebenarnya sudah memiliki konsep integrasi keilmuan, tetapi masih berbentuk 'bunga rampai' yang belum terformulasikan secara operasional. ${ }^{12}$

Salah satu bentuk implementasi lain yang dapat dilakukan oleh Fakultas Ushuluddin selain penerapan kurikulum adalah pada riset yang akan dihasilkan mahasiswanya. Riset dapat diarahkan pada upaya integrasi keilmuan, yaitu mengurai persoalan kekinian dengan mengawinkan pendekatan "wahyu" dan pendekatan "ilmiah". Dengan demikian, produk-produk riset fakultas tercinta ini dapat menawarkan nuansa baru yang holistik, terpadu antara 'verifikasi ilmiah' dan 'verifikasi teologis', serta menjadi upaya produktif (qirā'ah muntijjah), bukan upaya repetitif (qirāah mutakarrirah). Dalam rumusan lain, William $\mathrm{C}$. Chittick menyatakan bahwa kecerdasan tidak hanya dapat menangkap dan memahami hakikat sesuatu, tetapi juga mampu melahirkan sesuatu. Menurutnya, mengabaikan realitas, baik objek maupun subjek, berarti jatuh ke dalam kebodohan, kesalahan, dan khayalan. ${ }^{13}$

Mengakomodasi pendekatan sekular secara proporsional untuk mengkaji keislaman adalah sebuah keniscayaan. Hanya saja, penggunaan pendekatan dan kerangka teori apa pun harus dibarengi dengan evaluasi dan kritik yang konstruktif, supaya juga dapat menghasilkan temuan ilmiah yang merupakan perwujudan dari upaya integrasi keilmuan. Khazanah keilmuan klasik Islam adalah modal plus yang dimiliki Fakultas Ushuluddin, karena telah menjadi referensi utama dalam pembelajarannya. Hasilnya akan lebih mumpuni jika metodologi riset yang digunakan juga terus dikembangkan.

\footnotetext{
${ }^{12}$ Nurlena Rifai, Wahdi Sayuti Fauzan, dan Bahrissalim, "Integrasi Keilmuan Dalam Pengembangan Kurikulum Di Uin Se-Indonesia," TARBIYA Vol. 1, no. 1 (2014): 30-31, doi:10.15408/tjems.v1i1.1108..

${ }^{13}$ William Chittick, "Visi Antropokosmik dalam Pemikiran Islam," in Tuhan, Alam, Manusia: Perspektif Sains dan Agama, ed. Ted Peters, Muzaffar Iqbal, dan Syed Nomanul Haq, terj. Ahsin Muhammad (Bandung: Mizan, 2006), 170.
}

Mata kuliah yang terkait dengan studi Alquran di Fakultas Ushuluddin tersajikan tidak lagi dalam kerangka pengenalan, khususnya di Jurusan Ilmu Alquran dan Tafsir. Pada mata kuliah Tafsir yang disajikan hampir di setiap semesternya, mahasiswa disuguhkan materi tentang persoalan kekinian dengan mengakomodasi pendekatan ilmiah kekinian, sehingga menghasilkan produk pembelajaran yang up to date. Sebagai contoh, pembelajaran tentang masyarakat menurut perspektif Alquran, tidak lagi hanya sekadar menemukan legitimasi kewahyuannya, tetapi juga mengkaji dan mengembangkannya berdasarkan temuan mutakhir.

\section{Dari Realitas ke Teks}

Studi Alquran bertajuk tafsir mawḍu' $\bar{i}$ selama ini lebih didominasi oleh pendekatan dari teks ke realitas. ${ }^{14}$ Konsekuensinya adalah seorang pengkaji mencari kata kunci tertentu dan menghimpun ayat-ayat yang menyebutkannya, kemudian mencari dan mengaitkan penafsiran-penafsirannya. Metode ini banyak berkembang dan merupakan bentuk awal dari metode penafsiran tematik. Namun, seiring perkembangan, metode ini menuai kritik karena tidak mampu menjawab tuntutan kekinian yang banyak menawarkan sejumlah persoalan namun tidak ditemukan legitimasi kewahyuannya dalam Alquran.

Adalah pendekatan sebaliknya, yaitu dari realitas ke teks yang mendapatkan atensi peminat studi Alquran. Pendekatan ini memang terbilang lebih berat ditempuh daripada pendekatan sebelumnya. Pasalnya, topik tertentu dicarikan isyarat-isyaratnya dari sejumlah ayat Alquran, tanpa berpijak pada kata kunci yang pasti. Upaya ini menuntut kemampuan ekstra dari seorang pengkaji Alquran untuk memperoleh ayat-ayat yang terkait dengan topik yang dimaksud. Jika ayatayat tersebut telah ditemukan, barulah upaya penafsiran dilakukan.

${ }^{14}$ Istilah dari realitas ke teks merupakan terjemahan dari min al-Wāqi' ilā al-nas. Istilah yang mirip dengannya ini menjadi salah satu judul buku yang ditulis oleh Hassan Hanafi, yaitu Min al-Naș' ilā alWaqu'. 
Dalam upaya penafsiran tersebut, pendekatan dan informasi terkait diakomodasi untuk menambah bobot ilmiah dari kerangka penafsiran. Objek kajiannya pun semakin meluas dan mampu menyentuh persoalanpersoalan yang belum terbahas di pendekatan sebelumnya. Pendekatan terakhir ini adalah salah satu format pengkajian dalam studi Alquran yang dapat terus dikembangkan di lingkungan Fakultas Ushuluddin.

Dengan demikian, studi Alquran harus mengakomodasi upaya integrasi keilmuan, sehingga dikotomi keilmuan tidak terus mengemuka. Bukankah, tidak ada dikotomi antara ilmu sekuler dan ilmu agama. Sejarah mencatat bahwa pada abad VIII-XII M, dijumpai figur-figur sekaliber al-Farabi, alKindi, Ibn Rushd, Ibnu Tufail, dan seterusnya yang menguasai dua disiplin ilmu, baik ilmu agama maupun ilmu umum. ${ }^{15}$ Figur-figur tersebut memainkan peran dalam kemajuan dunia Barat modern saat ini.

Alquran juga sangat menafikan dikotomi keilmuan. Banyak ayat Alquran yang mengajak kita untuk memerhatikan ayat-ayat qawliyah maupun ayat-ayat kawniyah untuk menunjukkan tanda-tanda kekuasaan-Nya. Salah satunya, QS. Ali 'Imran 3: 190-191 yang menyebut kata ulul albāb yang dimaknai sebagai "orang yang berakal" meniscayakan terintegrasinya dua dimensi, yaitu dhikr dan fikr. Keduanya harus disandingkan untuk memperoleh bukti nyata tentang keesaan dan kekuasaan Allah SWT.

\section{SIMPULAN}

Upaya integrasi keilmuan dalam studi Alquran adalah sebuah kemestian untuk menjawab tantangan zaman. Ia juga menjadi prasyarat bagi perwujudan Fakultas Ushuluddin sebagai fakultas riset di lingkungan UIN SDG Bandung. Kiprah fakultas tercinta ini senantiasa dinantikan dalam mengawal kemajuan ilmiah dan akademik. Semoga almamater tercinta ini terus dapat

\footnotetext{
${ }^{15}$ Septiana Purwaningrum, "Elaborasi Ayat-Ayat Sains dalam Al-Quran: Langkah Menuju Integrasi Agama dan Sains dalam Pendidikan," Inovatif Vol. 1, no. 1 (2015): 125.
}

menghasilkan lulusan yang mumpuni menghadapi kemodernan. Lulusan yang memahami realitas kekinian dan mampu menjawab tuntutan kekinian yang banyak menawarkan sejumlah persoalan.

\section{DAFTAR PUSTAKA}

Abdullah, Amin. Islamic Studies di Perguruan Tinggi: Pendekatan IntegratifInterkonektif. Yogyakarta: Pustaka Pelajar, 2012.

Chittick, William. "Visi Antropokosmik dalam Pemikiran Islam." Dalam Tuhan, Alam, Manusia: Perspektif Sains dan Agama, diedit oleh Ted Peters, Muzaffar Iqbal, dan Syed Nomanul Haq, diterjemahkan oleh Ahsin Muhammad. Bandung: Mizan, 2006.

Ferdous, Fouzia, dan Muhammad Athar Uddin. "Toward Islamization of Science and Technology." IIUC Studies Vol. 9, no. 9 (2011): 233-42.

Jamal, Nur. "Model-Model Integrasi Keilmuan (Format Ideal Perguruan Tinggi Agama Islam)." Islamedia: Jurnal Kajian Keislaman Vol. 1, no. 1 (2011): 186-202.

Kementerian Agama RI. Penciptaan Manusia dalam Perspektif al-Qur'an dan Sains. Jakarta: Kemenag RI dan LIPI, 2012.

Kuntowijoyo. Islam sebagai Ilmu. Yogyakarta: Tiara Wacana, 2006.

Mohd Amin, W. Mohd Azam. "A Preliminary Analysis of The Classical Views of The Concept of Integration of Knowledge." Revelation and Sciences 04, no. 02 (2014): 12-22.

Purwaningrum, Septiana. "Elaborasi AyatAyat Sains dalam Al-Quran: Langkah Menuju Integrasi Agama dan Sains dalam Pendidikan." Inovatif Vol. 1, no. 1 (2015): 124-41.

Rifai, Nurlena, Wahdi Sayuti Fauzan, dan Bahrissalim. "Integrasi Keilmuan Dalam Pengembangan Kurikulum Di UIN SeIndonesia." TARBIYA Vol. 1, no. 1 (2014):13-34. doi:10.15408/tjems.v1i1.1108. 
Suprayogo, Imam. "Membangun Integrasi

Ilmu dan Agama: Pengalaman UIN

Malang." In Integrasi Ilmu dan Agama:

Interpretasi dan Aksi, diedit oleh Zainal

Abidin Bagir. Bandung: Mizan, 2005. 